\title{
The effect of the CGRP receptor antagonist (MK- 8825 ) on the response to trigeminal nociception in rodents
}

\author{
M Romero-Reyes ${ }^{1 *}, \mathrm{~S}$ Akerman ${ }^{2}$ \\ From The European Headache and Migraine Trust International Congress \\ London, UK. 20-23 September 2012
}

\section{Introduction}

Several highly prevalent and debilitating conditions involve pain in the trigeminal distribution. Although effective treatments exist, for many patients these treatments are far from optimal. Therefore understanding the pathophysiology of pain in the craniofacial region is critical. CGRP plays an essential role in the process of peripheral and central sensitization in the trigeminovascular system. Release of CGRP contributes to the process of neurogenic inflammation generating allodynia and hyperalgesia, clinical characteristics in neuropathic, inflammatory and migraine pain.

\section{Objectives}

To study the effect of the CGRP receptor antagonist, MK-8825, on responses to trigeminal nociception and trigeminal nucleus caudalis (TNC) activation, using a mouse model of trigeminal nociception.

\section{Methods}

C57BL/6 mice received either a subcutaneous injection of the MK-8825 $(70 \mathrm{mg} / \mathrm{kg})$ or vehicle alone, followed by an injection of $0.9 \%$ saline solution or complete Freund's adjuvant (CFA) in their right masseter muscle, shown previously to produce nociceptive-specific specific grooming behaviors. Animals were video recorded for assessment of nociceptive behaviors for one hour. Mice were overdosed with isoflurane and perfused transcardially at 2 or 24 hours after the MK- 8825 injection. The brainstem was removed the area of the TNC was prepared and reacted for Fos immunoreactivity to verify neuronal activation.

${ }^{1}$ NYU College of Dentistry, USA

Full list of author information is available at the end of the article

\section{Results}

Mice that received MK-8825, with CFA injection in the masseter, spent significantly less time exhibiting nociceptive behaviors compared to those that received vehicle $(\mathrm{P}<0.05)$. At 2 and 24hrs after CFA injection mice that received MK-8825 had a significantly lower level of Fos immunoreactivity in the ipsilateral TNC compared to those that received CFA and vehicle.

\section{Conclusion}

MK-8825 decreases pain behaviors and neuronal activation in the TNC of mice with inflammatory pain in the trigeminal mandibular distribution. CGRP likely contributes to the pathophysiological mechanism of this pain response.

\section{Conflicts}

Grant funding from MERCK Sharp \& Dohme Corp,

This work has been supported in part by a research grant from the Investigator Initiated Studies Program of Merck Sharp \& Dohme Corp and 2009 AHS/MRF Thomas E. Heftler Migraine Research Award. We want to thank Dr. Andrew Charles for helpful discussions.

\section{Conflicts}

Dr. Marcela Romero has received grant funding from Merck Sharp \& Dohme Corp to conduct this study. Dr. Simon Akerman has consulted for Merck Sharp \& Dohme Corp and MAP Pharmaceuticals

\section{Author details}

${ }^{1} \mathrm{NYU}$ College of Dentistry, USA. ${ }^{2}$ University of California, San Francsico, USA.

Published: 21 February 2013
(C) 2013 Romero-Reyes and Akerman; licensee Springer. This is an Open Access article distributed under the terms of the Creative Commons Attribution License (http://creativecommons.org/licenses/by/2.0), which permits unrestricted use, distribution, and reproduction in any medium, provided the original work is properly cited. 
doi:10.1186/1129-2377-14-S1-P93

Cite this article as: Romero-Reyes and Akerman: The effect of the CGRP receptor antagonist (MK-8825) on the response to trigeminal

nociception in rodents. The Journal of Headache and Pain 2013 14(Suppl 1):P93.

\section{Submit your manuscript to a SpringerOpen ${ }^{\circ}$} journal and benefit from:

- Convenient online submission

- Rigorous peer review

- Immediate publication on acceptance

- Open access: articles freely available online

- High visibility within the field

- Retaining the copyright to your article

Submit your next manuscript at $\gg$ springeropen.com 